\title{
DELAMINOMYCINS, NOVEL EXTRACELLULAR MATRIX RECEPTOR ANTAGONISTS
}

\section{BIOSYNTHESIS}

\author{
Mitsuhiro Ueno, Ihomi Yoshinaga, Masahide Amemiya, Tetsuya Someno, \\ Hironobu IINUma ${ }^{\dagger}$, MaSAaki IshizUaKa* and Tomio TakeUCHI \\ Institute for Chemotherapy, \\ Microbial Chemistry Research Foundation, \\ 18-24 Aza-Motono, Miyamoto, Numazu-shi, Shizuoka 410-03, Japan \\ 'Institute of Microbial Chemistry, \\ Microbial Chemistry Research Foundation, \\ 3-14-23 Kamiosaki, Shinagawa-ku, Tokyo 141, Japan
}

(Received for publication April 19, 1993)

The biosynthesis of delaminomycin A, produced by Streptomyces albulus MJ202-72F3, was investigated by feeding ${ }^{13} \mathrm{C}$-labeled compounds followed by ${ }^{13} \mathrm{C}$ NMR analyses. The results indicate that delaminomycin $\mathbf{A}$ is derived from six acetate units, five propionate units and one glycine unit.

In the course of screening for inhibitors of cell adhesion to fibronectin, laminin and collagen type IV, components of the extracellular matrix (ECM), we found new ECM antagonists, named delaminomycins, produced by Streptomyces albulus MJ202-72F ${ }^{1 \sim 4)}$. The major component was identified as delaminomycin A (1, Fig. 1). In this paper, we report incorporation experiments with single and multiple labeled ${ }^{13} \mathrm{C}$

Fig. 1. Structures of delaminomycin A (1) and its derivative (2).

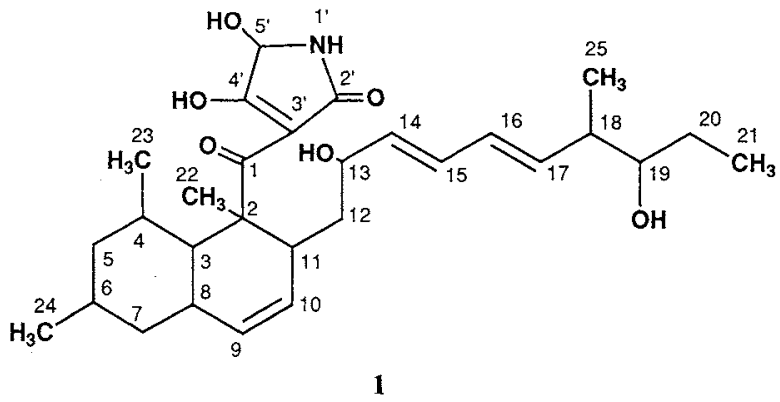

Delaminomycin A<smiles>CCC(O)C(C)C=CC=CC1CC2C=CC3CC(C)CC(C)C3C2(C)C(=O)C12C(=O)NC(O)C2=O</smiles> 
precursors to determine the biosynthetic origin of the carbon atoms of 1 .

\section{Materials and Methods}

\section{General Procedure}

TLC was carried out on Silica gel $60 \mathrm{~F}_{254}$ plates of $0.2 \mathrm{~mm}$ thickness (Merck, Art. No. 5554) using $\mathrm{CHCl}_{3}-\mathrm{MeOH}-\mathrm{NH}_{4} \mathrm{OH}(40: 10: 1)$ as the developing solvent. Detection of 1 and 2 (Fig. 1) on the TLC plate was carried out by a color reaction with the vanillin- $\mathrm{H}_{2} \mathrm{SO}_{4}$ reagent (purple red) or fluorescence quenching under $254 \mathrm{~nm}$ UV light. The Rf values of 1 and 2 were 0 and 0.67 , respectively.

HPLC analyses were carried out using a CAPCELL PAK $5 \mathrm{C}_{18}$ column (Shiseido, $4.6 \times 250 \mathrm{~mm}$ ) with a mobile phase of $\mathrm{MeOH}-\mathrm{CH}_{3} \mathrm{CN}-25 \mathrm{mM} \mathrm{NH}_{4} \mathrm{OAc}-2-\mathrm{PrOH}(30: 30: 35: 5)$ at a flow rate of $1.0 \mathrm{ml} / \mathrm{minute}$ equipped with a Hitachi $655 \mathrm{~A}-11$ pump, a Sugai U-620 PSH column heater set at $35^{\circ} \mathrm{C}$, a Hitachi L-4000 UV detector set at $235 \mathrm{~nm}$ and a Hitachi chromato-integrator. The retention time of 1 was 7.5 minutes.

Preparative HPLC was performed using a Gilson HPLC system controlled by NEC PC-9801 computer, Sugai U-620 PSH column heater set at $30^{\circ} \mathrm{C}$, SIC chromatocorder-21 and a YMC-Pack SH-343 ODS column $(20 \times 250 \mathrm{~mm})$.

${ }^{13} \mathrm{C}$ NMR spectra were measured in $\mathrm{CDCl}_{3}$ on a Jeol JNM-A400 instrument operating at $100 \mathrm{MHz}$. Enrichment ratios were determined from each signal intensity by comparison with spectra of unenriched positions and with that of unenriched material recorded under the same conditions.

\section{Labeled Compounds}

${ }^{13} \mathrm{C}$ precursors contained $>99$ atom $\%{ }^{13} \mathrm{C}$ at the labeled positions except for $\left[1-{ }^{13} \mathrm{C}\right]$ acetate $\left(98.6\right.$ atom $\%{ }^{13} \mathrm{C}$ ). Sodium $\left[1-{ }^{13} \mathrm{C}\right]$ acetate, sodium $\left[2-^{13} \mathrm{C}\right]$ acetate, sodium $\left[1,2-{ }^{13} \mathrm{C}\right.$ ] acetate, sodium $\left[1-{ }^{13} \mathrm{C}\right]$ propionate, DL- $\left[1-{ }^{13} \mathrm{C}\right]$ alanine, $\left[1,2-{ }^{13} \mathrm{C}\right.$ ] glycine and $\mathrm{L}-\left[\right.$ methyl- $\left.{ }^{13} \mathrm{C}\right]$ methionine were purchased from Sigma Chemical Co., U.S.A.

\section{Microorganism}

Streptomyces albulus MJ202-72F3 was used to produce 1.

\section{Fermentation}

Strain MJ202-72F3 on an agar slant was inoculated into a 500-ml Erlenmeyer flask containing $110 \mathrm{ml}$ of seed medium and cultured at $30^{\circ} \mathrm{C}$ for 3 days on a rotary shaker $(180 \mathrm{rpm})$. The seed medium consisted of glucose $1.5 \%$, yeast extract (Nippon-Seiyaku) $0.25 \%$, Casamino acids (Difco) $0.25 \%, \mathrm{CaCO}_{3} 0.4 \%$; the $\mathrm{pH}$ of the medium was not adjusted. Two $\mathrm{ml}$ of this seed culture was inoculated into $100 \mathrm{ml}$ of production medium in a $500-\mathrm{ml}$ Erlenmeyer flask and cultured at $28^{\circ} \mathrm{C}$ for 6 or 7 days on a rotary shaker $(180 \mathrm{rpm})$. The production medium consisted of glucose $3.0 \%$ yeast extract $0.5 \%$, Casamino acids $0.5 \%, \mathrm{NaNO}_{3}$ $0.2 \%, \mathrm{KCl} 0.2 \%, \mathrm{CaCO}_{3} 0.4 \%$; the $\mathrm{pH}$ of the medium was not adjusted.

After 3 days fermentation, at a suitable stage in delaminomycin production, cultures received the first addition of ${ }^{13} \mathrm{C}$-labeled precursor. In the case of $\left[1-{ }^{13} \mathrm{C}, 2-{ }^{13} \mathrm{C}, 1,2-{ }^{13} \mathrm{C}_{2}\right]$ acetate and $\left[1-{ }^{13} \mathrm{C}\right]$ propionate, precursors were added in doses of $0.05 \%(\mathrm{w} / \mathrm{v})$ at 72 and 120 hours after inoculation. DL- $\left[1-{ }^{13} \mathrm{C}\right]$ alanine, $\left[1,2-{ }^{13} \mathrm{C}_{2}\right]$ glycine and $\mathrm{L}-\left[\right.$ methyl $\left.-{ }^{13} \mathrm{C}\right]$ methionine were added in doses of $0.025 \%(\mathrm{w} / \mathrm{v})$ at $72,96,120$ and 144 hours after inoculation, and the cultures were incubated further for 24 hours.

\section{Preparation of ${ }^{13} \mathrm{C}$-Labeled 2}

Conversion of 1 to 2: Each fermentation broth $(500 \mathrm{ml})$ containing 1 labeled with a particular ${ }^{13} \mathrm{C}$-labeled precursor was centrifuged and the mycelium was extracted with $200 \mathrm{ml}$ of acetone. The extract was concentrated under reduced pressure to give an aqueous solution. The solution was extracted twice with $30 \mathrm{ml}$ of $n-\mathrm{BuOH}$. The organic layer was concentrated under reduced pressure. The crude material containing 1 was treated with $8 \mathrm{ml}$ of $1 \mathrm{~N} \mathrm{HCl}$ - acetone $(1: 3, \mathrm{v} / \mathrm{v})$ at room temperature for 17 hours. Under the treatment, 1 was converted to 2 , showing a main spot at $\mathrm{Rf} 0.67$ with the vanillin $-\mathrm{H}_{2} \mathrm{SO}_{4}$ reagent ${ }^{2}$.

Isolation of 2 : The reaction mixture containing 2 was concentrated under reduced pressure to give an aqueous solution. The solution was extracted with EtOAc. The organic layer was washed with saturated $\mathrm{NaCl}$, dried over anhydrous $\mathrm{Na}_{2} \mathrm{SO}_{4}$ and evaporated under reduced pressure. The residue was dissolved 
Table 1. Production of $\mathbf{1}$ in cultures and the yields of 2 .

\begin{tabular}{|c|c|c|c|c|}
\hline Expt. & Additives & $\begin{array}{c}\text { Production of } \\
\mathbf{1} \\
(\mu \mathrm{g} / \mathrm{ml})^{\mathrm{a}}\end{array}$ & $\begin{array}{c}\text { Amounts of } \\
2 \\
(\mathrm{mg})\end{array}$ & $\begin{array}{c}\text { Total } \\
\text { yield of } 2 \\
(\%)\end{array}$ \\
\hline \multirow[t]{3}{*}{ I } & None & $88^{\mathrm{b}}$ & 13.6 & 30.9 \\
\hline & Sodium $\left[2-{ }^{13} \mathrm{C}\right]$ acetate & $70^{b}$ & 9.4 & 26.9 \\
\hline & Sodium $\left[1,2-{ }^{13} \mathrm{C}_{2}\right]$ acetate & $62^{\mathrm{b}}$ & 6.8 & 21.9 \\
\hline \multirow[t]{2}{*}{ II } & None & 179 & - & - \\
\hline & $\mathrm{L}-\left[\right.$ Methyl- $\left.{ }^{13} \mathrm{C}\right]$ methionine & 65 & 5.6 & 17.2 \\
\hline \multirow[t]{4}{*}{ III } & None & 155 & - & - \\
\hline & Sodium $\left[1-{ }^{13} \mathrm{C}\right]$ acetate & 146 & 15.2 & 20.8 \\
\hline & $\mathrm{DL}-\left[1-{ }^{13} \mathrm{C}\right]$ Alanine & 270 & 28.0 & 20.7 \\
\hline & {$\left[1,2-{ }^{13} \mathrm{C}_{2}\right]$ Glycine } & 259 & 26.6 & 20.5 \\
\hline IV & Sodium $\left[1-{ }^{13} \mathrm{C}\right]$ propionate & 220 & 23.0 & 20.9 \\
\hline
\end{tabular}

a Determined by HPLC analysis.

b A shaker was out of order at 3rd day for 15 hours.

Table 2. ${ }^{13} \mathrm{C}$ NMR analysis of 2 enriched by incorporation of isotopic precursors.

\begin{tabular}{|c|c|c|c|c|c|c|}
\hline No. & $\begin{array}{l}\delta^{13} \mathrm{C} \\
\text { (ppm) }\end{array}$ & $\begin{array}{l}{\left[1-{ }^{13} \mathrm{C}\right]-} \\
\text { Acetate }\end{array}$ & $\begin{array}{l}{\left[2-^{13} \mathrm{C}\right]-} \\
\text { Acetate }\end{array}$ & $\begin{array}{c}{\left[1,2-{ }^{13} \mathrm{C}_{2}\right]-} \\
\text { Acetate }\end{array}$ & $\begin{array}{c}\mathrm{L}-\left[\text { Methyl }{ }^{13} \mathrm{C}\right]- \\
\text { methionine }\end{array}$ & $\begin{array}{c}{\left[1-^{13} \mathrm{C}\right]-} \\
\text { Propionate }\end{array}$ \\
\hline 1 & 212.2 & $2.36^{*}$ & 1.47 & 1.94 (N.C. $\left.^{b}\right)^{a}$ & 0.77 & $9.19^{* *}$ \\
\hline 2 & 54.3 & 1.09 & $2.93^{*}$ & $2.09(33.2)$ & 1.22 & 0.96 \\
\hline 3 & 43.6 & $2.99^{*}$ & 1.87 & $2.19(34.4)$ & 0.97 & $8.14^{* *}$ \\
\hline 4 & 35.5 & 0.84 & $3.05^{*}$ & $2.15(34.3)$ & 0.91 & 0.66 \\
\hline 5 & 47.2 & $3.16^{*}$ & 2.30 & $2.75(33.6)$ & 0.91 & $8.58^{* *}$ \\
\hline 6 & 33.1 & 1.06 & $3.76^{*}$ & $2.11(32.8)$ & 0.92 & 0.81 \\
\hline 7 & 42.3 & $7.46^{* *}$ & 1.45 & $1.87(33.6)$ & 0.96 & 0.96 \\
\hline 8 & 40.4 & 0.89 & $5.00^{* *}$ & $1.56(33.6)$ & 0.90 & 0.70 \\
\hline 9 & 130.6 & $7.06^{* *}$ & 1.19 & $1.09(48.0)$ & 0.94 & 0.93 \\
\hline 10 & 126.8 & 0.88 & $6.35^{* *}$ & $1.35(48.0)$ & 0.88 & 0.74 \\
\hline 11 & 46.1 & $7.35^{* *}$ & 1.18 & $1.47(32.0)$ & 1.01 & 0.93 \\
\hline 12 & 32.0 & 0.99 & $6.94^{* *}$ & $1.84(32.2)$ & 1.00 & 0.83 \\
\hline 13 & 44.1 & $5.43^{* *}$ & 0.88 & $1.21(44.3)$ & 0.84 & 1.03 \\
\hline 14 & 128.8 & 0.95 & $5.85^{* *}$ & $1.41(44.3)$ & 1.00 & 0.84 \\
\hline 15 & 133.8 & $6.06^{* *}$ & 0.99 & $1.24(54.9)$ & 0.86 & 0.91 \\
\hline 16 & 129.9 & 0.68 & $5.15^{* *}$ & $1.32(54.9)$ & 0.78 & 0.68 \\
\hline 17 & 137.4 & $1.96^{*}$ & 1.24 & $1.59(43.5)$ & 0.70 & $8.05^{* *}$ \\
\hline 18 & 41.9 & 0.89 & $3.18^{*}$ & $2.30(41.2)$ & 0.92 & 0.74 \\
\hline 19 & 76.6 & $3.33^{*}$ & 1.42 & $1.61(38.1)$ & O.L. ${ }^{d}$ & $4.97^{* *}$ \\
\hline 20 & 26.4 & 0.72 & $3.53^{*}$ & $3.04(38.2)$ & 0.78 & 0.77 \\
\hline 21 & 10.5 & 1.06 & $3.73^{*}$ & $3.09(35.1)$ & 0.82 & 0.93 \\
\hline 22 & 17.1 & 1.08 & $3.93^{*}$ & $2.97(37.3)$ & 0.97 & 1.00 \\
\hline 23 & 18.9 & 1.02 & $3.20^{*}$ & $2.22(34.3)$ & 0.95 & 0.87 \\
\hline 24 & 22.1 & 1.11 & $3.31^{*}$ & $2.50(35.1)$ & 1.02 & 0.96 \\
\hline 25 & 14.1 & 1.19 & $3.23^{*}$ & $2.39(35.8)$ & 1.10 & 0.99 \\
\hline $2^{\prime}$ & 168.5 & $2.86^{*}$ & 0.66 & $0.95(47.3)$ & 0.48 & 0.79 \\
\hline $3^{\prime}$ & 72.4 & 1.22 & $5.21 * *$ & $1.83(47.3)$ & 1.31 & 1.21 \\
\hline $4^{\prime}$ & 205.5 & 0.60 & 0.60 & 1.11 (N.C.) & 0.60 & 1.00 \\
\hline $5^{\prime}$ & 79.5 & $1.00^{\mathrm{c}}$ & $1.00^{\mathrm{c}}$ & $1.00^{\mathrm{c}}$ & $1.00^{\mathrm{c}}$ & $1.00^{\mathrm{c}}$ \\
\hline
\end{tabular}

a $J$-values are in parentheses $(\mathrm{Hz})$.

b Not coupled.

- Relative enrichments were normalized to peak intensities for the C-5' signal.

d Overlapped with solvent peak.

* Low level of enrichment was observed.

** High level of enrichment was observed. 
in acetonitrile and applied to a reverse phase HPLC column (YMC-pack ODS, 20 $\times 250 \mathrm{~mm}$ ) and eluted with $80 \%$ acetonitrile. Fractions containing 2 were collected and concentrated under reduced pressure, loaded onto a Sephadex LH-20 column $(65 \mathrm{ml})$ and eluted with acetonitrile. The fractions containing 2 were concentrated to give a white powder.

\section{Results and Discussion}

As described in our previous papers ${ }^{1,2)}$, the major component of delaminomycins in the fermentation broth and mycelium was 1 ; however, the ${ }^{13} \mathrm{C}$ NMR spectrum of 1 was very complicated due to the presence of possible equilibrium structures. Thus, we converted $\mathbf{1}$ to $\mathbf{2}$ in order to clarify the mode of incorporation of ${ }^{13} \mathrm{C}$-labeled precursors by ${ }^{13} \mathrm{C}$ NMR spectroscopic analyses.

As shown in Table 1, feeding of DL- $\left[1-{ }^{13} \mathrm{C}\right]$ alanine, $\left[1,2-{ }^{13} \mathrm{C}_{2}\right]$ glycine and sodium $\left[1-{ }^{13} \mathrm{C}\right]$ propionate enhanced the production of 1 , but feeding of $\mathrm{L}-\left[\right.$ methyl $\left.{ }^{13} \mathrm{C}\right]$ methionine inhibited growth of the producing strain and reduced the production of delaminomycins including 1 in cultures. Throughout these incorporation experiments, total yields of ${ }^{13} \mathrm{C}$ labeled 2 after purification were between 17 to $31 \%$.

The ${ }^{13} \mathrm{C}$ NMR spectra of 2 derived from $\left[1-{ }^{13} \mathrm{C}\right]$ acetate, $\left[2-{ }^{13} \mathrm{C}\right]$ acetate, $\left[1-{ }^{13} \mathrm{C}\right]$ propionate and $\left[1,2-{ }^{13} \mathrm{C}_{2}\right]$ glycine are shown in Fig. 2. The numbering depicted in the signals indicates the enriched carbon signals. The enriched ratio and ${ }^{13} \mathrm{C}-{ }^{13} \mathrm{C}$ coupling constants of ${ }^{13} \mathrm{C}$-labeled 2 are listed in Table 2. Enrichment ratios were calculated from the relative intensity of $\mathrm{C}-5^{\prime}$ as 1.0 . As shown in Table 2, enrichment of carbons C-7, 9, 11, 13, $15,2^{\prime}$ by $\left[1{ }^{13} \mathrm{C}\right]$ acetate and $\mathrm{C}-8,10,12,14,16,3^{\prime}$ by $\left[2-{ }^{13} \mathrm{C}\right]$ acetate were observed. ${ }^{13} \mathrm{C}-{ }^{13} \mathrm{C}$ coupling constants of $\left[1,2-{ }^{13} \mathrm{C}_{2}\right]$ acetate-labeled 2 were equal in couples of carbons. These results indicate the incorporation of acetate into a pentaketide chain (C-7 to 16) and a single acetate unit (C-2' and C-3'). As enriched signals were not observed in $\mathrm{C}-4^{\prime}$ and $\mathrm{C}-5^{\prime}$, these carbons are thought to be derived from another precursor(s). The low level of incorporation of $\left[2-{ }^{13} \mathrm{C}\right]$ acetate into all methyl carbons (C-21, 22, 23,24 and 25) and carbons adjacent to these methyl groups (C-2, 4, 6, 18 and 20) suggest the metabolism of $\left[2{ }^{13} \mathrm{C}\right]$ acetate to propionate with consequent label dilution before incorporation at these sites.

To confirm this hypothesis, incorporation experiments using $\mathrm{L}-\left[\right.$ methyl $\left.-{ }^{13} \mathrm{C}\right]$ methionine and $\left[1-{ }^{13} \mathrm{C}\right]$ propionate were performed. As shown in Table 2, no enriched signals were observed in any

Table 3. ${ }^{13} \mathrm{C}$ NMR analysis of 2 enriched with stable isotope precursors.

\begin{tabular}{|c|c|c|c|}
\hline \multirow{2}{*}{ No. } & \multirow{2}{*}{$\begin{array}{l}\delta{ }^{13} \mathrm{C} \\
\text { (ppm) }\end{array}$} & \multicolumn{2}{|c|}{ Relative enrichments } \\
\hline & & {$\left[1,2-{ }^{13} \mathrm{C}_{2}\right]$ Glycine } & {$\left[1-^{13} \mathrm{C}\right]$ Alanine } \\
\hline 1 & 212.2 & $1.00^{\mathrm{a}}$ & $1.00^{\mathrm{a}}$ \\
\hline 2 & 54.3 & 1.08 & 1.19 \\
\hline 3 & 43.6 & 0.95 & 1.41 \\
\hline 4 & 35.5 & 0.91 & 1.21 \\
\hline 5 & 47.2 & 1.07 & 1.36 \\
\hline 6 & 33.1 & 1.04 & 1.29 \\
\hline 7 & 42.3 & 0.67 & 1.35 \\
\hline 8 & 40.4 & 0.57 & 1.30 \\
\hline 9 & 130.6 & 0.66 & 1.28 \\
\hline 10 & 126.8 & 0.60 & 1.16 \\
\hline 11 & 46.1 & 0.59 & 1.42 \\
\hline 12 & 32.0 & 0.55 & 1.30 \\
\hline 13 & 44.1 & 0.61 & 1.02 \\
\hline 14 & 128.8 & 0.62 & 1.34 \\
\hline 15 & 133.8 & 0.60 & 1.16 \\
\hline 16 & 129.9 & 0.61 & 1.11 \\
\hline 17 & 137.4 & 0.97 & 0.91 \\
\hline 18 & 41.9 & 0.91 & 1.07 \\
\hline 19 & 76.6 & 1.04 & O.L. ${ }^{b}$ \\
\hline 20 & 26.4 & 1.17 & 0.92 \\
\hline 21 & 10.5 & 1.37 & 1.30 \\
\hline 22 & 17.1 & 1.25 & 1.57 \\
\hline 23 & 18.9 & 1.13 & 1.45 \\
\hline 24 & 22.1 & 1.07 & 1.41 \\
\hline 25 & 14.1 & 1.17 & 1.64 \\
\hline $2^{\prime}$ & 168.5 & 0.63 & 0.71 \\
\hline $3^{\prime}$ & 72.4 & 0.73 & 1.61 \\
\hline $4^{\prime}$ & 205.5 & $4.76^{* *}$ & 0.82 \\
\hline $5^{\prime}$ & 79.5 & $5.13 * *$ & 1.36 \\
\hline
\end{tabular}

a Relative enrichments were normalized to peak intensities for the C-1 signal of 2 .

b Overlapped with solvent peak.

** High level of enrichment was observed. 
Fig. 2. ${ }^{13} \mathrm{C}$ NMR spectra of 2 derived from labeled precursors in $\mathrm{CDCl}_{3}$.

(A) $\left[1-{ }^{13} \mathrm{C}\right]$ acetate, (B) $\left[2-{ }^{13} \mathrm{C}\right]$ acetate, (C) $\left[1-{ }^{13} \mathrm{C}\right]$ propionate, (D) $\left[1,2-{ }^{13} \mathrm{C}_{2}\right]$ glycine, (E) natural abundance.

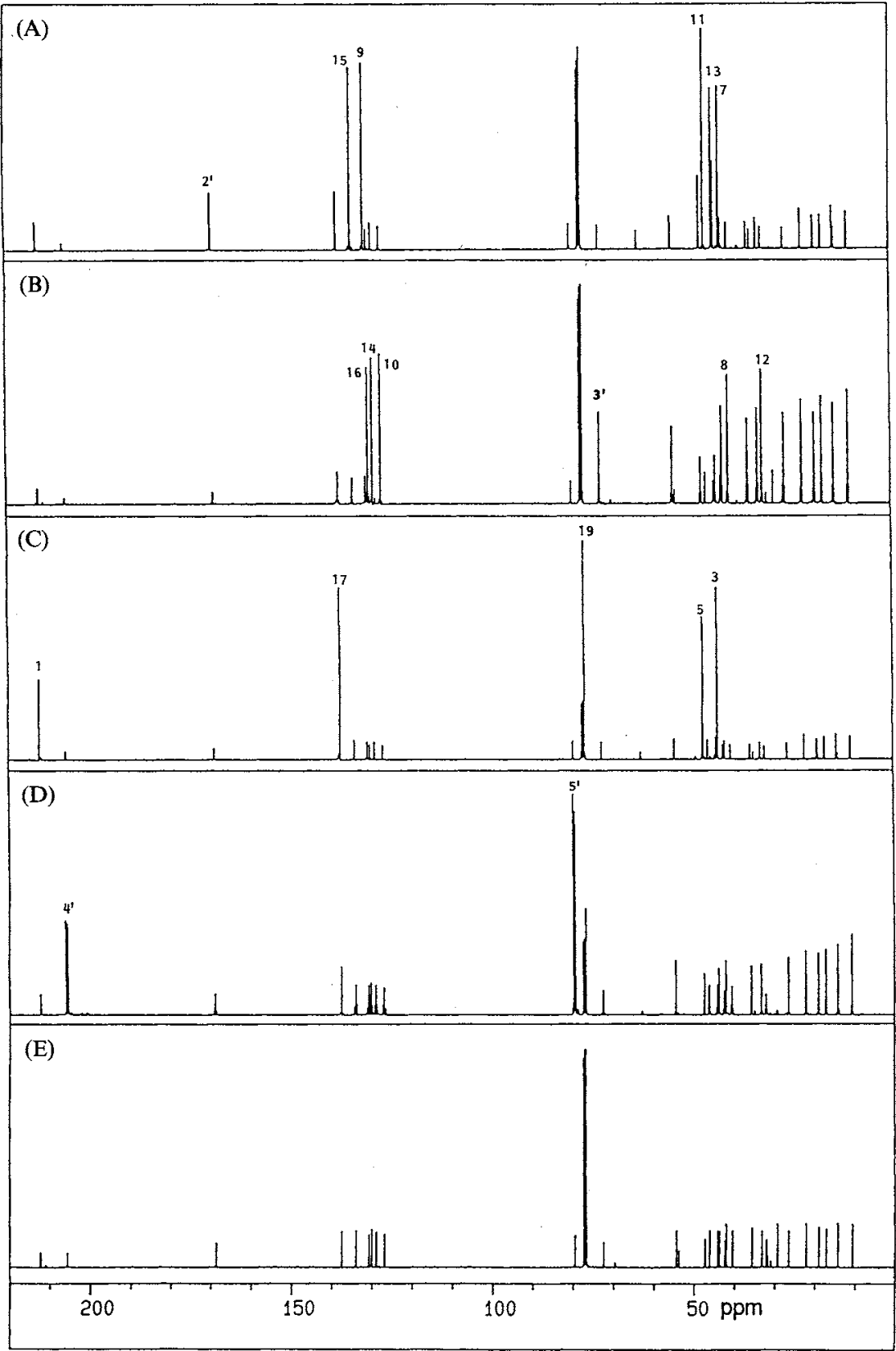

methyl carbon (C-21, 22, 23, 24 and 25). This indicates that these atoms are not derived from S-adenosylmethionine. As shown in Table 2 and Fig. 2, enriched signals were observed in C-1, 3, 5, 17 and 19. This indicates the incorporation of five propionate units into 2 . These results support the hypothesis described above. 
Fig. 3. Signals for $\mathrm{C}-4^{\prime}$ and $\mathrm{C}-5^{\prime}$ in $100 \mathrm{MHz}{ }^{13} \mathrm{C}$ NMR spectrum of 2 labeled by $\left[1,2-{ }^{13} \mathrm{C}_{2}\right]$ glycine. $J_{4^{\prime}, 5^{\prime}}=42.8 \mathrm{~Hz}$
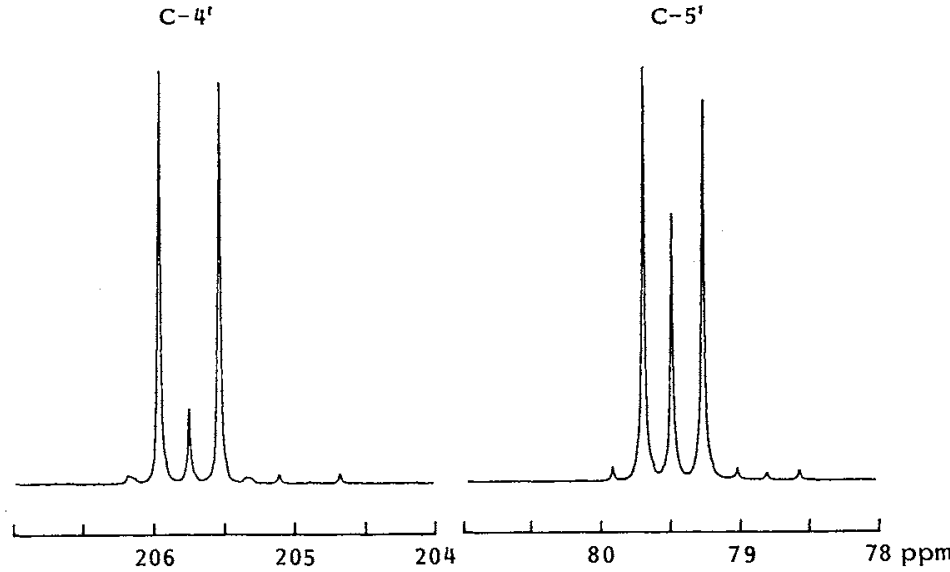

Fig. 4. Labeling patterns in delaminomycin $\mathrm{A}$ derived from ${ }^{13} \mathrm{C}$-labeled precursors.

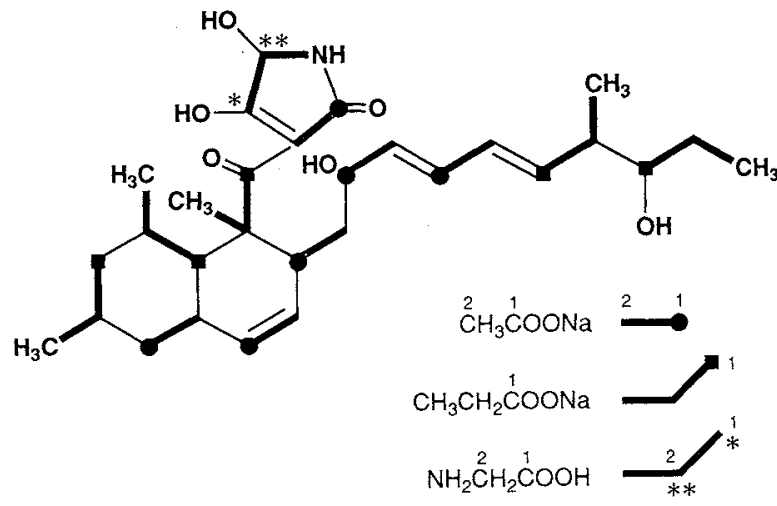

Fig. 5. Proposed biosynthetic scheme for delaminomycins A, B and C.

$\mathrm{HOOCCH} \mathrm{NH}_{2}$

glycine

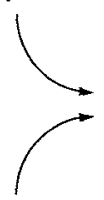<smiles>O=C1NCC(O)=C1S</smiles>
hydroxylation HO<smiles>O=C1NC(O)C(O)=C1[Hg]</smiles><smiles>COC1NC(=O)C(S)=C1O</smiles>

$\mathrm{CH}_{3} \mathrm{COOH}$ acetic acid

The incorporation data for DL- $\left[1-{ }^{13} \mathrm{C}\right]$ alanine and $\left[1,2-{ }^{13} \mathrm{C}_{2}\right]$ glycine into 2 are shown in Table 3 . Enrichment ratios were calculated from the relative intensity of $\mathrm{C}-1$ as 1.0 . With $\left[1,2-{ }^{13} \mathrm{C}_{2}\right]$ glycine, enriched signals were observed at $\mathrm{C}-4^{\prime}$ and $5^{\prime}$ with a coupling constant of $J_{4^{\prime}, 5^{\prime}}=42.8 \mathrm{~Hz}$ as shown in Figs. 2 and 3. The results indicate the intact incorporation of glycine into the pyrrolidine moiety. No 
incorporation was observed into 2 from DL- $\left[1-{ }^{13} \mathrm{C}\right]$ alanine.

The results obtained from the above feeding experiments with ${ }^{13} \mathrm{C}$-labeled precursors demonstrate that one mole of delaminomycin $\mathrm{A}$ is biosynthesized from six moles of acetate, five moles of propionate and one mole of glycine. Hence, the origin of the all carbon atoms of delaminomycin A has been established and can be summarized as shown in Fig. 4.

In the feeding experiment with $\left[1,2-{ }^{13} \mathrm{C}_{2}\right]$ glycine, labeled glycine was highly incorporated into the delaminomycin molecule. This result suggests that intact glycine is incorporated into delaminomycin $\mathrm{C}$. Thus, it appears that delaminomycin $\mathrm{C}$ is biosynthesized first and is a precursor for delaminomycins $\mathrm{A}$ and $\mathrm{B}$. Therefore, the biosynthetic pathway to delaminomycins can be considered to be as shown in Fig. 5. First, delaminomycin $\mathrm{C}$ is biosynthesized by the incorporation of glycine into pyrrolidine moiety. Second, delaminomycin $\mathrm{C}$ is hydroxylated enzymatically to delaminomycin $\mathrm{A}$. Third, delaminomycin $\mathrm{A}$ is methylated enzymatically to delaminomycin B.

Acknowledgment

This work was supported in part by a Grant-in-Aid for Cancer Research from the Ministry of Education, Science and Culture, Japan.

\section{References}

1) Ueno, M.; M. Amemiya, M. Iuima, M. Osono, T. Masuda, N. Kinoshita, T. Ikeda, H. Iinuma, M. Hamada, M. ISHIZUKA \& T. TAKEUCHI: Delaminomycins, novel nonpeptide extracellular matrix receptor antagonist and a new class of potent immunomodulator. I. Taxonomy, fermentation, isolation and biological activity. J. Antibiotics 46: $719 \sim 727,1993$

2) Ueno, M.; T. Someno, R. Sawa, H. Invma, H. Naganawa, M. Ishizuka \& T. Takeuchi: Delaminomycins, novel nonpeptide extracellular matrix receptor antagonist and a new class of potent immunomodulator. II. Physicochemical properties and structure elucidation of delaminomycin A. J. Antibiotics 46: 979 984, 1993

3) Ueno, M.; T. Someno, R. Sawa, H. Innuma, H. Naganawa, M. Ishizuka \& T. TAkeuchi: Delaminomycins, novel extracellular matrix receptor antagonist. III. Physico-chemical properties and structure elucidation of delaminomycins B and C. J. Antibiotics 46: 1020 1023, 1993

4) Ueno, M.; M. Amemiya, K. Yamazaki, M. Iujma, M. Osono, T. Someno, H. Innuma, M. Hamada, M. Ishizuka \& T. TAKEUCHI: Delaminomycins, novel extracellular matrix receptor antagonist. IV. Structure-activity relationships of delaminomycins and derivatives. J. Antibiotics 46: 1156 1162, 1993 